\section{СПИСОК ВИКОРИСТАНОЇ ЛІТЕРАТУРИ}

1. Иосиф де Каласанс: биография. URL: http:// www.people.su/45813 (дата звернення: 10.11.2015).

2. Пиары в Лиде // Город Лида. URL: https://1lida. org/article/a-68.html (дата звернення: 23.11.2015).

3. Св. Иосиф Каласанс, священник // Радио Ватикана. URL: http://ru.radiovaticana.va/news/2015/08/25/25 B8/1167396 (дата звернення: 18.11.2015).

4. Buba J. O założeniach organizacyjnych pierwszych szkół pijarskich w Italii i w Polsce w XVII wieku / J. Buba // Kultura i literatura dawnej Polski. - Warszawa : Państw. Wydawn. Naukowe, 1967. - S. 489-532.

5. Buba J. Założyciel pijarów - «znaki czasu» / J. Buba // Pijarzy w kulturze dawnej Polski: ludzie i zagadnienia: praca zbiorowa. - Kraków : Polska Prowincja XX Pijarów, 1982. - S. 15-21.

6. Gołek B. Pedagogia pijarów [Zakonu Kleryków Regularnych Ubogich Matki Bożej Szkół Pobożnych] / B. Gołek // Pedagogie katolickich zgromadeń zakonnych: historia i współczesność. T. 1. Redakcja naukowa Janina Kostkiewicz. - Kraków : Impuls, 2012. - S. 133-161.

7. Gołek B. Współczezny wymiar pijarskiego dzieła wychowawczego. URL: http://www.pedkat.pl/ images/czasopisma/pk11/PK11a08.pdf (дата звернення: 18.08.2016).

8. López S. Dokumenty św. Józefa Kalasancjusza / S. López. - Kraków : Polska Prowincja Zakonu Pijarów, Wydawnictwo eSPe, 2007. - $410 \mathrm{~s}$.

9. Matras J. O. SP. Historia życia św. Józefa Kalasancjusza / J. Matras // Życie oddane wychowaniu: Św. Józef Kalasancusz 1557 - 1648: jubileusz 450. rocznicy urodzin Założyciela pijarów. - Kraków : Polska Prowincja Zakonu Pijarów, Wydawnictwo eSPe, 2008. - S. 22-33.
10. Możdżen S.I.Historiawychowaniado 1795/S.I.Możdżen. - Kielce : Wydawnictwo Diecezjalne, 2005. - 431 s.

11. Pedagogika Pijarska // Polska Prowincja Zakonu Pijarów. URL: http://www.pijarzy.pl/zalozyciel/pedagogika_pijarska/patron_uczniow_i_nauczycieli_d6857_ pol.html (дата звернення: 12.08.2016).

12. Pitala A. ks. Pijarskie zakłady kształcenia nauczycieli w dawnej Polsce - profesoria A. Pitala // Wkład pijarów do nauki i kultury w Polsce XVII - XIX wieku / pod red. nauk. Ireny Stasiewicz-Jasiukowej. - Warszawa ; Kraków : Zakład Historii Nauk Społecznych Instytutu Historii Nauki, Oświaty i Techniki PAN: Polska Prowincja Pijarów, 1993. - S. 391-408.

13. Pijarzy // Zycie Zakonne: Serwis informacyjny konferencji wyższych przełożonych zakonów męskich w Polsce. URL: http://www.zyciezakonne.pl/informator/ zakony-meskie/pijarzy-355/ (дата звернення: 07.08.2016).

14. Rychlicki J. Pedagogika Św. Józefa Kalasancjusza // J. Rychlicki / Pijarzy w kulturze dawnej Polski: ludzie i zagadnienia: praca zbiorowa. - Kraków : Polska Prowincja XX Pijarów, 1982. - S. 22-39.

15. Saint Joseph Calasanz // Annus lubilaei Scholarum Piarum. URL: http://scolopi.org/en/calasanz/ (дата звернення: 18.11.2015).

16. Sobolewska-Strzelczak B. Początki szkolnictwa Pijarskiego. Inspiracje dla współczesnej teorii i praktyki pedagogicznej / B.Sobolewska-Strzelczak // Perspektiva. Legnickie Studia Teologiczno-Historyczne. - 2013. № 2 (23). - S. 159-168.

17. Taraszkiewicz J. Pierwsze stulecie zakonu pijarów na ziemiach Rzeczypospolitej Obojga Narodów $(1642-1740)$ / J. Taraszkiewicz. - Gdańsk : Wydawnictwo Uniwersytetu Gdańskiego, 2015. - 362 s.

Дата надходження до редакиії: 28.10.2019 p.

\section{Марія ЮЗИк,}

аспірантка кафедри педагогіки

Національного університету біоресурсів

і природокористування Украйни, м. Київ

\title{
РОЗВИТОК ПЕДАГОГІЧНОЇ МАЙСТЕРНОСТІ МАЙБУТНІХ УЧИТЕЛІВ ПОЧАТКОВОЇ ШКОЛИ В ЗАКЛАДАХ ВИЩОЇ ОСВІТИ УКРАЇНИ ТА СЛОВАЧЧИНИ
}

У статті окреслено сутність та особливості педагогічної майстерності у процесі підготовки майбутніх учителів початкової школи. Зроблено порівняльний аналіз особливостей вступної педагогічної практики, яку проходять студенти на базі закладів освіти в Украӥні та Словаччині.

Ключові слова: вчитель початкової школи, ключові компетентності, факультетська школа, педагогічна практика, педагогічна майстерність, портфоліо, креативність.
В статье обозначены сущность и особенности педагогического мастерства в процессе подготовки будуших учителей начальной школь. Сделан сравнительный анализ особенностей вступительной педагогической практики, которую проходят студенть на базе учебньх заведений в Украине и Словакии.

Ключевые слова: учитель начальной школь, ключевые компетентности, факультетская школа, педагогическая практика, педагогическое мастерство, портфолио, креативность. 
The research requires careful study and identification of the peculiarities of the preparation and formation of key competencies of future primary school teachers in the vocational training of Slovakia and Ukraine. In the context of the development of key competences for pupils, the primary education teacher is a key personality. The change of the role of elementary school teacher in the duties of which was previously tasked to solve, manage, explain, control, today - to motivate, activate, help, advise, coordinate, diagnose, create a favorable atmosphere is analyzed. The question of the formation of key competences is considered as one of the key goals of learning in today's fast-paced world is the preparation of a person for life-long learning. It has been proved that every faculty preparing future teachers should have a faculty school where students go through pedagogical practice, and teachers experimentally introduce new ideas, implement pedagogical research and so on. The purpose of the modern elementary school teacher is to develop a person capable of life-giving and self-realization in the new rapidly changing conditions, emerging as a change in social life and consciousness. In solving these problems, a key role is assigned to the elementary school teacher, who today needs to take a fresh look at his work, including the construction of the lesson, the form of its conduct, as well as to learn new methods of teaching younger students.

The basics of teachers' pedagogical skills development are highlighted, the UNESCO document is mentioned, which first of all emphasizes the change of the teacher's role, in particular, it is stated that teachers who start their pedagogical activity should duly accept the fact that pedagogical improvement is not only a mandatory process and permanent, but one that will last throughout their professional career. Key Competencies are based on the European Key Competence Framework, with an emphasis on the values and needs of our school system. The acquisition of key competences represents a long and complex process that begins already during the pre-primary education period, then continues in primary and secondary education.

Key words: elementary school teacher, key competencies, faculty school, pedagogical practice, pedagogical skill, portfolio, creativity.

Актуальність. Завдання, які ставить перед сучасною освітою суспільство, вимагають зміни позиції вчителя. Якщо ще вчора на нього було покладено завдання вирішувати, керувати, пояснювати, контролювати, то сьогодні - мотивувати, активізувати, допомагати, радити, координувати, діагностувати, створювати сприятливу атмосферу, розвиваючи таким чином особистість учнів. Учитель повинен розуміти процес онтогенетичного розвитку дитини, iї навчання та особистісного становлення, знати, як дидактично пов'язати навчання 3 віковими та індивідуальними особливостями учнів. При цьому особлива увага зосереджується на інтерперсональних компетенціях вчителя (тобто його вмінні створювати в колективі соціоемоційну атмосферу, підтримувати позитивні інтерперсональні відносини 3 дітьми, емпатію, комунікативні навички, вміння працювати в групі) та «себерефлексії» - вмінні аналізувати та оцінювати власну педагогічну діяльність, особисте ставлення до дітей, проектувати і реалізувати особистісні зміни та саморозвиток [2, с. 314].

Таким чином, формування педагогічної майстерності майбутнього вчителя початкової школи розпочинається під час навчання у закладі вищої освіти і триває впродовж усього життя.

Виклад основного матеріалу. Питання формування педагогічної майстерності вчителів, зокрема і тих, що викладають у початкових класах, розглядали чимало дослідників і науковців, як-от: Й. Ватутуха, Р. Дітртова, Ю. Івановічова, Б. Касачова, 3. Колларікова, Б. Косова, Д. Коструб, Б. Мурінова, М. Пішова, Л. Подлахова, С. Покривчакова, Е. Северіні, Н. Теличко, I. Турек, О. Шимонік та ін.

Так, О. Шимонік звертає увагу на переважання теоретичної підготовки означеної категорії студентів над практичною. Б. Мурінова характеризує розвиток комунікативних компетентностей студентів - майбутніх учителів початкових класів. Ю. Івановічова окреслює стан та перспективи підготовки студентів у закладах вищої освіти до майбутньої професійної діяльності, роблячи акцент на педагогічну практику. Н. Теличко зауважує, що до підготовки вчителя початкової ланки нині слід підходити по-новому, адже сьогодення диктує нові «вимоги до формування у майбутніх педагогів високого рівня професійної психолого-педагогічної підготовки, вміння творчо працювати на ниві навчання і виховання молодших школярів, самостійно приймати науково-обгрунтовані, своєчасні та правильні рішення, виявляючи зразки педагогічної майстерності» [5, с. 7].

Мета статті - окреслити сутність та особливості педагогічної майстерності у процесі підготовки майбутніх учителів початкової школи; порівняти особливості вступної педагогічної практики, яку проходять студенти на базі закладів освіти в Україні та Словаччині.

Виклад основного матеріалу. Розвиток особистості, здатної до життєтворчості та самореалізації в нових швидкозмінюваних умовах постає як зміна в суспільному житті та свідомості. Адже сьогодні народжується нова школа, в якій учень зможе повноцінно жити, проектувати своє майбутнє, свій життєвий шлях, проявляючи власні здібності та можливості, маючи бажання до самовдосконалення, самоосвіти та самовиховання [4].

Місія сучасного вчителя і школи - навчити дітей бути гнучкими до змін, легко адаптуватися і вміти навчатися впродовж усього життя. Щоб це вдалося, щоб виховати креативного і творчого учня, вчителеві самому треба бути зразком, уміти мотивувати дітей до розвитку, до знань, до пізнання світу.

У вирішенні означених проблем ключову роль відведено саме вчителеві початкових класів, якому сьогодні необхідно по-новому подивитися на свою роботу, зокрема на побудову уроку, форми його проведення, а також засвоїти нові методи роботи з молодшими школярами [7, с. 314].

Однією зі складових педагогічної майстерності $\epsilon$ креативність - продукт нового мислення, під яким розуміємо творчі здібності індивіда, що характеризуються здатністю до продукування принципово нових ідей. У зв'язку з цим виокремлюють креативність суб'єктивну (індивідуальну) та об'єктивну (суспільну). У нашому випадку зосередимося на суб' єктивній креативності, яка передбачає наявність таких складових, як: швидкість - уміння швидко і легко відтворювати кількість психологічних продуктів, наприклад, слів, думок, образів, символів; гнучкість - уміння вирішувати різноманітні проблеми; оригінальність - уміння створити щось незвичайне та своєрідне; 
чутливість - уміння побачити проблему та з розумінням підійти до її вирішення тощо [1, с. 104].

Креативність надзвичайно тісно пов'язана із творчістю. Це - комплексний феномен, який має певні когнітивні, афективні, соціальні, біологічно-фізіологічні аспекти. Під творчістю, складовими якої $\epsilon$ оригінальність та активність, розуміють процес пошуку нових і необхідних (зокрема для особистості зокрема та суспільства в цілому) продуктів і рішень.

Творчість учителів - це вміння по-особливому підійти до виховання дітей та вирішення складних педагогічних ситуацій, застосовуючи при цьому ініціативність, самостійність і новаторство, використовуючи нові методи та форми роботи, вдаючись до імпровізації [2, с. 151].

Однією із ключових цілей навчання в сучасному глобалізованому світі є підготовка особистості до навчання впродовж життя. А це, як відомо, тісно пов'язане із формуванням ключових компетентностей. На сьогодні, на жаль, ні в Україні, ні в Словаччині немає самостійного предмета, який би був виключно спрямований на формування ключових компетентностей.

Уміння раціонально вчитися, ефективно шукати i використовувати інформацію є важливими для учнів початкової школи на наступному етапі їх навчання в загальноосвітній школі. Означену проблематику, як обов'язкову для всіх студентів - майбутніх педагогів, на наше глибоке переконання, мають включити у свої навчальні плани усі педагогічні факультети ЗВО.

Проаналізуємо, як до цього питання ставляться у Словаччині.

Так, відповідно до статті 25 «Хартії вчителів», прийнятої ЮНЕСКО, майбутні вчителі, які вивчають педагогічні дисципліни у закладах вищої освіти, повинні мати досвід викладання в школах, і цей досвід має бути підкріплений практичною підготовкою. Означена вимога у більшості випадків у діяльності словацьких учительських факультетів не дотримується. Зокрема, у підготовці вчителів вона досі відсутня. При цьому керівництво закладів вищої освіти зазвичай формальне, а співпраця цих закладів між собою недостатня. Як наслідок - мотивація викладачів $\epsilon$ досить низькою (у зв'язку з недостатнім фінансуванням), а педагогічні дослідження зведені до мінімуму. При цьому значна кількість викладачів ніколи не працювали в школі (а це - неприпустимо!), для якої готують кадри [6, с.126].

Іван Турек, вивчаючи сучасний стан післядипломної освіти в Словаччині як основу розвитку педагогічної майстерності вчителів, звертається до документа ЮНЕСКО, в якому наголошується на зміні ролі вчителя, зокрема зазначається, що вчителі, які починають свою педагогічну діяльність, як належне повинні прийняти той факт, що педагогічне вдосконалення - процес не лише обов'язковий і постійний, а й такий, що триватиме впродовж усієї їхньої професійної кар'єри.

До основних принципів післядипломної освіти вчителів відносять:

- безперервність, що забезпечується самоосвітньою діяльністю, а також набуттям нових знань і вмінь на основі вивчення відповідних предметів;

- охоплення післядипломною освітою всіх без винятку учасників процесу навчання та виховання, а саме: вчителів, викладачів університетів, інспекторів та інших педагогічних працівників;

- створення організованої структури системи післядипломної освіти вчителів із належним фінансовим забезпеченням, яка б давала їм змогу брати участь у різних формах педагогічного вдосконалення; у створенні означеної системи, формулюванні ії цілей, змісту, досліджень мають брати участь усі зацікавлені - зокрема учителі та директори шкіл [6, c. 127].

У 1997 - 1999 роках словацькими науковцями Туреком, Земаном та Якубцовою було проведено дослідження щодо ставлення словацьких педагогічних працівників до власного професійного вдосконалення. У дослідженні взяло участь 1679 випадково обраних педагогічних працівників, які викладали в початкових, середніх та старших класах школи або так чи інакше були дотичні до освітнього процесу.

На запитання «Як ви ставитеся до нинішньої ситуації в словацькій освіті?» опитані відповіли таким чином:

- 70,1\% - вважають теперішню ситуацію в освіті надзвичайно складною, навіть набагато гіршою, ніж вона була до листопада 1989 року;

- 93,5\% - зауважують, що післядипломна освіта надзвичайно потрібна (при цьому вчителі всіх типів шкіл і всіх навчальних предметів вважають сучасну систему післядипломної освіти педагогічних працівників гіршою, ніж вона була у Словаччині до 1989 року);

- 39,6\% - переконані, що за сучасних умовах розвитку освіти будь-яке навчання та вдосконалення не має сенсу;

- більше половини педагогів (і це викликає тривогу) не зацікавлені у подальшому вдосконаленні власної педагогічної майстерності, адже головним фактором цього є низька заробітна плата;

- 55,1\% - основною причиною своєї відсутності на заходах методично-педагогічних центрів та інших інституцій, спрямованих на післядипломну освіту педагогічних працівників, вважають недостатню мотивацію (їх ніхто не мотивує до такої участі, а самі вони цього не прагнуть). Стосовно інших причин такої ситуації вони називають: недостатнє фінансування $(42,4 \%)$; низький рівень проведених заходів $(25,1 \%)$; організацію заходів у вільний від роботи час (16,7\%); небажання керівництва школи надати їм можливість відвідати означені заходи у робочий час $(9,7 \%)$; $13,7 \%$ опитаних оцінили діяльність методично-педагогічних центрів позитивно, 49,9 \% - нейтрально, $36,4 \%$ - негативно [6, с. 128].

У Словаччині наявна проблема недостатньої практичної підготовки випускників педагогічних факультетів, що є наслідком їх недостатньої мобільності. Для прикладу, підготовка майбутніх учителів у коледжах Німеччини вважається взірцевою в усьому світі саме завдяки грунтовно продуманій та організованій педагогічній практиці студентів. До речі, у передвоєнній Чехословаччині підготовка майбутніх учителів була на високому рівні саме завдяки якісній педагогічній практиці.

Відомо, що будь-які знання й уміння будуть більш ефективними, якщо вони закріплені на практиці. Кожен факультет, який готує майбутніх педагогів, повинен мати свою факультетську школу (на зразок лікарських факультетів, які мають власні факультетські лікарні), де б студенти проходили педагогічну практику, а викладачі експериментально впроваджували нові ідеї, реалізовували педагогічні дослідження тощо. Факультетські школи повинні бути частиною факультету, а їх організацію та діяльність слід передбачити законодавством. 
Учительська професія передбачає високі вимоги до всебічного розвитку майбутніх педагогів. Наприклад, перебуваючи на педагогічній практиці, майбутній учитель повинен вирішувати різноманітні питання та проблеми, пов'язані насамперед зі спілкуванням 3 учнями, а також їхніми батьками. Зокрема, йдеться не про проблеми, пов'язані з учителькою спеціалізацією, а передусім - суспільні, культурні, мистецькі, адже хто, як не вчитель, покликаний брати активну участь у культурно-суспільній діяльності.

Так, до навчального плану педагогічного факультету варто включити предмети, спрямовані на всебічний розвиток студентів. Сьогодні всі вчительські факультети Словаччини мають лише один суспільний предмет - філософію. Які саме предмети необхідні - слід вирішувати на громадських слуханнях. Зокрема, до таких предметів варто було б додати обов'язкове вивчення двох іноземних мов (як одна iз вимог Європейського Союзу), а також інформаційно-комунікаційних технологій, які на сьогодні є невід’ємною складовою нашого життя і без оволодіння якими неможливо уявити сучасну освічену людину. Наприклад, щоб довести свої знання у володінні комп'ютером, кожен студент, а також викладач закладу вищої освіти має скласти іспит на отримання « $\mathrm{C}_{\mathrm{B}}$ ропейської ліцензії на користування комп'ютером» (ECDL - European Computer Driving Licence) - сертифікат, який дає змогу випускникам стати конкурентоздатними на ринку праці та підвищить їхні шанси у пошуках роботи. На сьогодні в Словаччині дві тисячі студентів і молодих викладачів завдяки національній програмі «IT-Академія - Освіта XXI століття» мають можливість отримати такий сертифікат безкоштовно [6, c. 132].

Міжнародний сертифікат ECDL можна отримати не лише 3 інформатики, а й з інших суміжних галузей, зокрема: 1) М2 - Основи роботи 3 комп'ютерами; 2) М3 - Обробка тексту; 3) M4 - Калькулятор електронних таблиць; 4) М5 - Використання баз даних; 5) М6 - Презентація; 6) М7 - Основи роботи в мережі Інтернет; 7) M9 - Робота 3 зображеннями та графікою; 8) M12 - Безпека у використанні IКТ. Тестування на отримання сертифіката проводитимуть акредитовані центри, зокрема факультет менеджменту та інформатики Жилінського університету та Університет імені Павла Йозефа Шафарика в Кошицях. У випадку значної зацікавленості студентів з інших університетів, тестування проводитимуться у відповідному університеті [8].

Міріама Груба, яка надала нам інформацію про педагогічну практику магістрів початкової освіти на педагогічному факультеті в Університеті імені Амоса Коменського в Братиславі, $є$ керівником даної практики. Окреслимо деякі важливі моменти цієї практики.

Практика передбачає наявність щодня двох студентів в одному класі. Коли один студент проводить урок, другий спостерігає за ним, записує свої спостереження в спеціальний «лист спостережень». Закріплений за студентом учитель здійснює аналіз його навчальної діяльності за день, зосереджуючи основну увагу на трьох аспектах:

1) предмет навчальної програми;

2) дидактичний аспект навчального плану;

3) взаємодія у системах «студент - учитель» та «студент - учень».

Завдання студента під час практики - створення практичного портфоліо - низки необхідних документів (проект, різноманітні дидактичні матеріали, оригінальні матеріали, аналізи уроків, фотографії, нотатки, саморефлексія студента, пропозиції вчителя 3 безперервного навчання студента та ін.), що підтверджують реалізацію його практичної, навчальної та педагогічної діяльності.

Пропонуємо ознайомитися зі змістом та обов'язками студента в ході вступної педагогічної практики: 26.11. - 30.11. $2018 \mathrm{p}$.

- студенти знайомляться із середовищем початкової школи, розпорядком, правилами поводження в класах (якщо такі є), викладачами, дидактичними засобами та педагогічною документацією (журнал, розклад, шкільні програми, тематичні навчальні плани тощо);

- основне завдання студентів упродовж першого тижня практики - спостерігати за діяльністю вчителя, записувати спостереження до «листа спостережень»;

- студенти не повинні бути пасивними, навпаки, вони мають брати активну участь у навчальному процесі (за згодою вчителя), зокрема допомагати педагогу в організації уроків, проведенні частини уроку тощо;

- студенти беруть участь в організаційних заходах, наприклад, слідкують за порядком у класі, допомагають учням у їдальні або роздягалці;

- на наступний тиждень студент отримує від учителя тему уроку, який він має підготувати самостійно; з цією метою вчитель проводить для студента короткий інструктаж, аби до 30.11 він міг оцінити виконане завдання;

- до портфоліо можна додати коротку характеристику школи, розклад занять, модель навчання, інші педагогічні документи, записи спостережень, аналізи уроків тощо.

$$
\text { 3.12. - 7.12. } 2018 \mathrm{p} \text {. }
$$

- на цьому тижні студент буде залучений до викладання одного уроку на день (студент/урок/день);

- до кожного уроку необхідно грунтовно підготуватися;

- під час проведення уроку першим студентом другий присутній студент буде спостерігати за його діяльністю і робити нотатки;

- решта часу слід приділити спостереженню за педагогічною діяльністю вчителя;

- після проведення уроків учитель разом зі студентами аналізує їх;

- спостереження, проведення та аналіз уроків, саморефлексія студентів варто додати до матеріалів портфоліо.

\section{$10.12-21.12 .2018 p$}

- упродовж означених двох тижнів студенти викладатимуть усі предмети під наглядом учителя, а отже, із ним вони узгоджують свій подальших розклад та консультуються щодо проведення занять.

10.12. - 14.12 - перший студент щодня викладає: математику (обов'язковий предмет) + один необов'язковий предмет (природничі дисципліни), вітчизняні дослідження, фізичне виховання, музику, образотворче мистецтво, трудове навчання; відповідно другий студент - словацьку мову та літературу (обов'язковий предмет) + один необов'язковий предмет (природничі дисципліни), вітчизняні дослідження, фізичне виховання, музику, образотворче мистецтво, трудове навчання.

17.12. - 21.12. - студенти обмінюються дисциплінами, тобто перший студент викладає словацьку мову та літературу (обов'язковий предмет) + один необов'язковий предмет (природничі дисципліни), 
вітчизняні дослідження, фізичне виховання, музику, образотворче мистецтво, трудове навчання; відповідно другий студент - математику (обов'язковий предмет) + один необов'язковий предмет (природничі дисципліни), вітчизняні дослідження, фізичне виховання, музику, образотворче мистецтво, трудове навчання.

Словацькі науковці Душан Коструб та Єва Северіні, розглядаючи значення портфоліо під час студентської практики, наголошують на його ключовій ролі у навчанні впродовж життя. При цьому важливо зосередити увагу на тому, ЩО студент вивчає і ЯК навчається. Сторінки портфоліо мають бути розроблені таким чином, щоб якомога грунтовніше представити загальний розвиток студента. Структура кожної сторінки має бути розроблена за одним і тим же зразком це полегшує студентам роботу із портфоліо.

Переглядаючи час від часу власне портфоліо та аналізуючи його, студент не лише окреслює свою діяльність, а й бачить власну траєкторію росту. Портфоліо - це власність студента, але вчитель допомагає йому його укладати.

Портфоліо у педагогіці - це продукт, створений студентом, що містить важливу інформацію, окреслює розвиток особистості, завдяки йому можна оцінити загальний розвиток особистості протягом певного навчального періоду; воно полегшує і вчителю, і студенту відображення процесу навчання. Студентські портфоліо допомагають учителям скласти загальне враження про студента й оцінити його знання, вміння, а також творчі задатки.

Оскільки кожен студент проходить певні етапи формування особистості, саме завдяки портфоліо він отримує можливість обирати ті продукти, які, на його думку, є найбільш ефективні. Так, при створенні портфоліо можна скористатися низкою інструментів (блокнот, щоденник, дитячі малюнки, картинки, фотографії, аудіозаписи тощо). Таким чином, портфоліо студента може включати не лише його власні надбання, а й інформацію, примітки та спостереження вчителя, додані до нього.

Концепція портфоліо являє собою комплексний набір матеріальних і нематеріальних продуктів навчального предмета (а отже, і студента) впродовж певного періоду часу і точно фіксує поточний рівень студента, його прогрес, $є$ підгрунтям для його подальшого зростання. Концепція портфоліо відповідає поточному розумінню оцінювання, тому бажано відмовитися від оцінювання його викладачем, а вдатися, наприклад, до самооцінювання студентом або спільного оцінювання його роботи іншими студентами [3].

Пропонуємо порівняти навчальну практику словацьких студентів із педагогічною практикою в Україні, зокрема у Миколаївському національному університеті імені В. Сухомлинського. У програмі навчальної педагогічної практики у початковій школі для студентів спеціальності 013 «Початкова освіта» навчальна практика проводиться на III курсі (2-й семестр, 3 тижні). На практику відведено 54 години, тобто 1,5 кредита ECTS.

Студентів розподіляють на групи по 4-5 осіб. Перебуваючи щодня в школі не менше 6 годин, вони виконують завдання, передбачені програмою практики. Кожен студент, керуючись завданнями і змістом практики, веде педагогічний щоденник, в якому фіксує результати виконання завдань, аналізує роботу вчителів і діяльність учнів, а також власну діяльність.
Основний зміст роботи студента-практиканта виконання визначених програмою завдань, однак позитивним моментом $є$ активне включення студентів в освітній процес, допомога вчителю.

Мета практики: формування в студентів цілісного уявлення про навчально-виховний комплекс сучасної початкової школи і вчителя як головного суб'єкта навчально-виховного процесу в початковій школі.

Завдання практики:

1. Формування професійного інтересу до педагогічної діяльності вчителя початкової школи, створення в студентів установки на формування професійної позиції.

2. Вивчення специфіки праці вчителя (функції i професійні обов'язки педагога початкової школи).

3. Стимулювання потреби у формуванні культури педагогічної діяльності.

4. Уміння вести записи спостережень, обробляти, узагальнювати отриману в ході спостережень інформацію, повно і правильно відображати іїі в щоденнику практики.

5. Розвиток потреби в самопізнанні й самовдосконаленні.

6. Формування умінь спостереження, аналізу та оцінки навчально-виховного процесу в початковій школі, його відповідності програмним вимогам.

7. Оволодіння студентами засобами елементарної діагностики особистості та діяльності вчителя, індивідуальних особливостей дитини та класу в цілому.

Педагогічна (асистентська) практика у закладах вищої освіти передбачає практичну професійно-педагогічну підготовку студентів магістратури до викладання фахових дисциплін, ознайомлення їх 3 організацією навчально-виховного процесу в педагогічному ЗВО, набуття вмінь, необхідних для майбутнього викладача. У ході самостійної викладацької діяльності студенти-практиканти вдосконалюють уміння спостерігати і аналізувати педагогічний процес, структурувати навчальний матеріал із відповідної дисципліни, добирати оптимальні моделі навчання студентів, використовуючи сучасні надбання методики викладання у вищій школі, керувати самостійною навчальною та науково-дослідною роботою студентів, застосовувати різні види контролю знань та рівня сформованості практичних умінь та навичок студентів тощо.

Програма асистентської практики також передбачає виконання студентами магістратури обов'язків куратора академічної групи, завданням якого $€$ організація різноманітних форм виховної роботи зі студентами, вивчення студентського колективу, вироблення вмінь налагоджувати стосунки зі студентами й викладачами. Асистентська педагогічна практика поглиблює інтерес студентів до обраного фаху, розвиває педагогічні та творчі здібності, сприяє виробленню власного стилю педагогічної діяльності.

Висновки. Отже, педагогічна практика - один із найважливіших етапів професійної підготовки фахівця у галузі початкової освіти. Вона сприяє поглибленню і закріпленню теоретичних знань, формуванню професійних умінь і навичок. Саме під час педагогічної практики студенти переконуються у правильності обрання майбутньої професії, в наявності педагогічних здібностей, схильності до роботи з дітьми. Співпраця студентів-практикантів із досвідченими вчителями-наставниками під час педагогічної практики закладає основи педагогічної майстерності, любові до майбутньої професії. 


\section{СПИСОК ВИКОРИСТАНОЇ ЛІТЕРАТУРИ}

1. Карбовнічек Й. Малий лексикон дошкільної та початкової педагогіки / Й. Карбовнічек // Ружемберок. - Вербум, 2013. - 202 с.

2. Колар 3. Викладацький словник 3 педагогіки / 3. Колар. - Прага, 2012. - 192 с.

3. Обдржалек 3. Організація і менеджмент навчання : термінологічний і викладацький словник / 3. Обдржалек. - Братислава, 2004. - 420 c.

4. Станіславчук I. Розвиток креативного мислення учнів початкових класів через використання творчих завдань / I. Станіславчук. URL: https://dorobok.edu.vn.ua/article/view/2003 (дата звернення: 10.08.2019).

5. Теличко Н. В. Теорія і методика формування основ педагогічної майстерності майбутнього вчителя початкових класів : монографія / Н. В. Теличко. - Л. : Кондор, 2014. - 552 c.
6. Турек I. Дидактика / I. Турек. - Братислава, 2008. $-596 \mathrm{c}$

7. Юзик М. А. Тенденції розвитку системи підготовки майбутніх учителів початкової школи в умовах реформування освіти / М. А. Юзик // Молодий вчений. - № 8. - 2017. - С. 314-318.

8. Európsky vodičský preukaz na počítač. URL: https://www.minedu.sk/europsky-vodicsky-preukaz-napocitac/ (дата звернення: 15.07.2019).

9. Kostrub D. Portfólio v pedagogickej praxi študenta / D. Kostrub, E. SeveriniIn: Učitelské praxe - současné poznatky a perspektivy. - Brno : Masarykova univerzita, 2016. - S. 150-156.

Дата надходження до редакиії: 11.09.2019 p. 